\title{
Hepatic Triacylglycerol Lipase
}

National Cancer Institute

\section{Source}

National Cancer Institute. Hepatic Triacylglycerol Lipase. NCI Thesaurus. Code C82875.

Hepatic triacylglycerol lipase (499 aa, $256 \mathrm{kDa}$ ) is encoded by the human LIPC gene. This protein is involved in the metabolism of lipids. 